\title{
Dynamics of Internal Migration in Bangladesh
}

\author{
A.K.M. Nurun Nabi \\ Department of Sociology \\ University of Alberta \\ Edmonton, Alberta, Canada
}

\begin{abstract}
Inter-regional net migration rates for Bangladesh have been estimated using the available data set from the 1974 and 1981 census reports. A multiple regression model of internal migration in Bangladesh has failed to support the argument that internal migratory flows are determined by high population density. The development of the agrarian social structure of this country is rooted in the historical evolution of the land tenure system. The analysis indicates support for the argument that the unequal hierarchical relations of people to the land in Bangladesh condition the process by which migration takes place.
\end{abstract}

\section{Résumé}

On a estimé les taux de migration inter-régionale nette au Bangladesh à partir de données tirées des états de recensement de 1974 et 1981 . Un modèle de tégression multiple de la migration interne n'a pas permis de confirmer l'hypothèse selon laquelle les courants migratoires internes seraient déterminés par une forte densité de population. Le développement de la structure sociale agraire de ce pays est enraciné dans l'évolution des régimes fonciers. L'analyse étaye quelque peu l'argument soutenant que l'inégalité des liens hiérarchiques entre les gens et les terres détermine le processus de migration.

Key Words: internal migration, population density, unequal land relations

\section{Introduction}

Despite being a favourite topic of research in the less developed countries (Simmons et al., 1977), internal migration has never been the subject of rigorous and sustained study in Bangladesh. Studies have been conducted on spatial change and distribution of various population characteristics including migration (e.g., Obaidullah, 1967; Khan, 1969; Elahi, 1972; Hussain, 1972; Stoeckel et al., 1972; Huq, 1973; Chaudhury and Curlin, 1975; Haque, 1977; Chaudhury, 1978; Krishnan and Rowe, 1978; and Begum, 1979). While some of them are of excellent quality, others are of limited value in terms of data quality and representativeness. The general attempts have been to analyze and interpret the process in terms of the symptoms or the immediate determinants (for example, economic or occupational opportunities). Very few have linked migration to the traditional agrarian relations of production in the country, which influence people's behaviour in many ways. This study estimates the patterns of inter-regional migration for the census period of 1974-81, and attempts a regression representation of some selected determinants of net migration in Bangladesh. 


\section{Data and Methodology}

The data sources for this study are the available 1974 and 1981 population census reports. While the 1974 census included questions on place of birth, residence and duration of residence, the 1981 census did not. This left the option of indirect estimation of internal migration in Bangladesh for the period under study. Following the United Nations' manual on Methods of Measuring Internal Migration (1970), the census survival ratio method is used for the estimation. The census figures are taken as they are furnished by the census reports. The intercensal period is seven instead of ten years. This seven-year time frame may seem to be too short to have much significance for migration flows and their determinants, but it is sufficient to provide an indication of the pattern and determinants of. internal migration in Bangladesh, especially in a cross-sectional analysis. Corrections for this unusual intercensal period are made by interpolating the given age groups through the use of the Sprague Multipliers (United Nations, 1956:68). In the absence of required data in the 1974 census report, an age-gender specific distribution of population for each district is created using the national proportions, assuming that the differences between the national and the district level age-gender specific proportions do not vary too much. Support for this assumption can be found in the district level age-gender specific distribution of population for 1981 (Bangladesh Bureau of Statistics, 1984:54-56).

Because census data provide only retrospective information on migration for those alive at the date of observation (Kosinski, 1975:108), and persons below 15 years are generally dependent on parents and live with the family, the estimates of net migration for each district are calculated for population 17 years and over in 1981 over the population 10 years and over in 1974. The selection of 17 years instead of $15^{\prime}$ years as the cut-off point is made because of the correction through interpolation for the seven-year intercensal period of 1974-81. Rates are calculated using the appropriate 1981 population as the denominator.

The ordinary least squares regression technique is used for the analysis of the effects of the determinants of internal migration. The variables are entered into the regression equation in a predetermined order. This may imply a causal structure among the independent variables, but the formulation of a causal model is not within the scope of this study. However, the order of the variables in entering the equation was decided on the basis of knowledge gained from experience and the literature review. The selection of the operational measures pertaining to variables used in the regression model is dictated by the available data. The data are from the 1974 census, assuming that migration took place as a reaction to 
the situation at the beginning of the study period. However, where data are lacking for certain measures from the 1974 census, 1981 census figures are used as proxies.

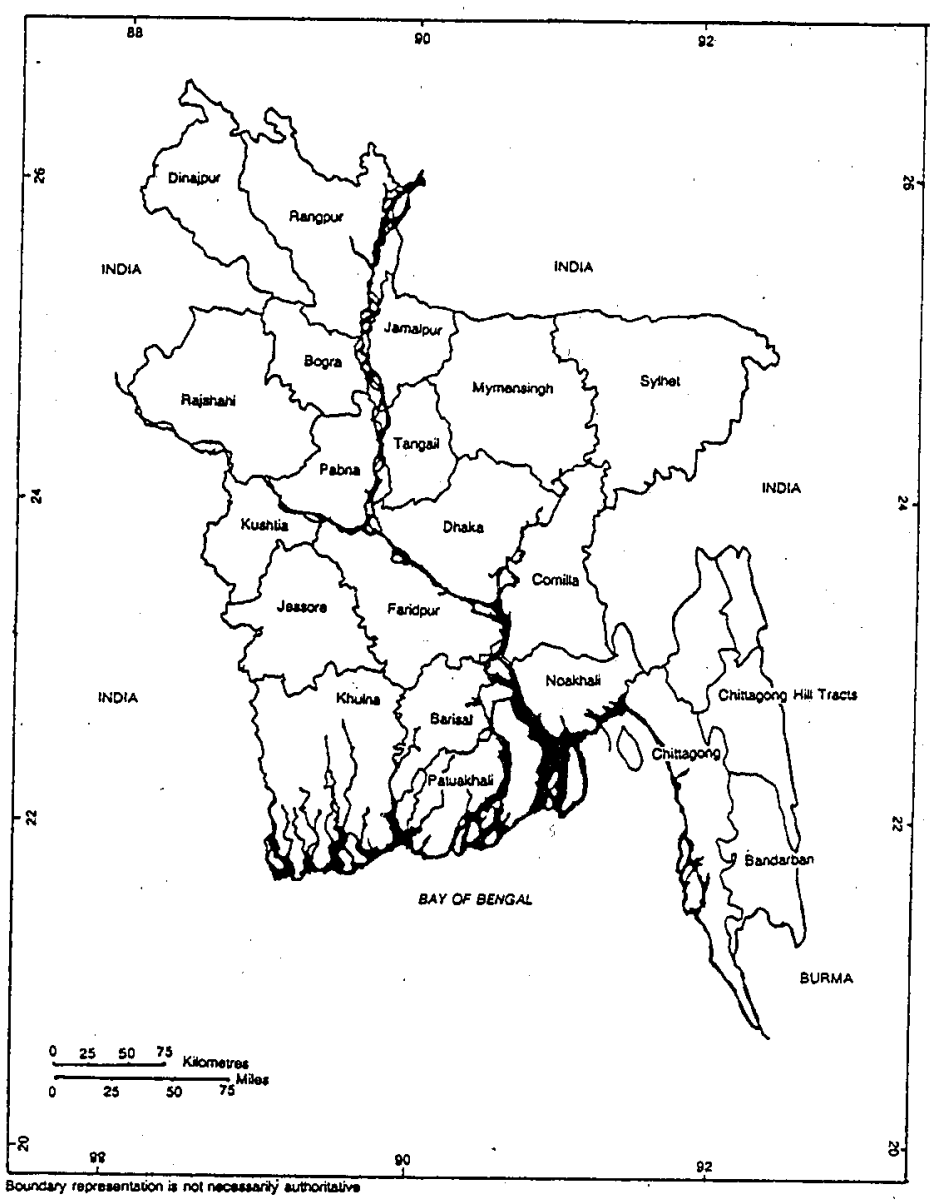

FIGURE 1. BANGLADESH DISTRICTS, 1981

Bangladesh consists of 21 districts according to the 1981 census. A map of . these districts is shown in Figure 1. The population in these districts ranges from 0.2 million to more than 10 million. The extreme cases in both ends of the scale are Dhaka, Chittagong Hill Tracts and Bandarban. Dhaka district has a population of more than 10 million because it contains the largest city of the country with a population of some 4 million. Chittagong Hill Tracts has a population of only approximately 0.6 million because of 
its geographical characteristics. Bandarban is a newly created district with a population of approximately 0.2 million. These 21 districts are the units of analysis in this study.

\section{TABLE 1. CENSUS SURVIVAL ESTIMATES OF NET MIGRATION BY REGIONS, BANGLADESH, 1974-1981}

\begin{tabular}{|c|c|c|c|c|c|c|}
\hline \multirow[b]{2}{*}{ Regions } & \multicolumn{3}{|c|}{ Net Migrants 1974-1981 } & \multicolumn{3}{|c|}{ Rate per 100 of 1981 Population } \\
\hline & Both Sexes & Male & Female & Both Sexes & Male & Female \\
\hline $\begin{array}{l}\text { Northern Region } \\
\text { Districts }\end{array}$ & 146,024 & 77,361 & 44,607 & 0.7 & 0.7 & 0.4 \\
\hline \multicolumn{7}{|l|}{ Districts } \\
\hline $\begin{array}{l}\text { Dinajpur } \\
\text { Rangpur }\end{array}$ & 33,014 & 20,361 & 15,022 & 1.0 & 1.2 & 1.0 \\
\hline Rangpur & $-22,727$ & $-28,716$ & 3,258 & -0.3 & -0.9 & 0.1 \\
\hline Bogra & 42,857 & 25,880 & 14,250 & 1.6 & 1.9 & 1.1 \\
\hline Rajshahi & 105,447 & 82,214 & 23,574 & 2.0 & $3.0^{-}$ & 0.9 \\
\hline Pabna & $-21,125$ & $-14,277$ & $-4,532$ & -0.7 & -0.9 & -0.9 \\
\hline Southern Region & $-237,083$ & $-75,751$ & $-157,427$ & -1.4 & -0.9 & -1.9 \\
\hline \multicolumn{7}{|l|}{ Districts } \\
\hline $\begin{array}{l}\text { Kushtia } \\
\text { Jessore }\end{array}$ & $\begin{array}{l}-39,598 \\
-57,099\end{array}$ & $\begin{array}{l}-16,090 \\
-20,049\end{array}$ & & $\begin{array}{l}-1.7 \\
-1.4\end{array}$ & $\begin{array}{l}-1.4 \\
-1.0\end{array}$ & $\begin{array}{l}-2.1 \\
-2.2\end{array}$ \\
\hline $\begin{array}{l}\text { Jessore } \\
\text { Khulna }\end{array}$ & $\begin{array}{l}-57,099 \\
-1,636\end{array}$ & $\begin{array}{r}-20,049 \\
18,214\end{array}$ & $\begin{array}{r}-42,168 \\
24,626\end{array}$ & $\begin{array}{l}-1.4 \\
-0.0^{\mathrm{a}}\end{array}$ & $\begin{array}{r}-1.0 \\
0.8\end{array}$ & $\begin{array}{l}-2.2 \\
-1.2\end{array}$ \\
\hline $\begin{array}{l}\text { Khulna } \\
\text { Patuakhali }\end{array}$ & $-12,132$ & $\begin{array}{r}10,217 \\
-6,129\end{array}$ & $-7,601$ & -0.7 & -0.7 & -0.8 \\
\hline Barisal & $-110,787$ & $-51,456$ & $-57,377$ & -2.4 & -2.2 & -2.5 \\
\hline Central Region & 255,167 & 164,059 & 108,138 & 1.0 & 1.2 & 0.9 \\
\hline \multicolumn{7}{|l|}{ Districts } \\
\hline Faridpur & $-129,714$ & $-83,939$ & $-37,268$ & -2.7 & -3.5 & -1.6 \\
\hline Dhaka & 493,264 & 360,023 & 142,345 & 4.9 & 6.7 & 3.1 \\
\hline Tangail & $-48,424$ & $-38,566$ & $-12,143$ & -2.0 & -3.1 & -1.0 \\
\hline Mymensingh & $-45,009$ & $-102,270$ & 2,914 & -0.7 & -3.0 & 0.1 \\
\hline Jamalpur & $-7,383$ & $-20,272$ & 11,701 & -0.3 & -1.6 & 1.0 \\
\hline Eastern Region & $-157,759$ & $-149,465$ & $-32,996$ & -0.7 & -1.3 & -0.3 \\
\hline \multicolumn{7}{|l|}{ Districts } \\
\hline $\begin{array}{l}\text { Sylhet } \\
\text { Comilla }\end{array}$ & $-70,795$ & $-35,708$ & $-27,242$ & -1.3 & $\begin{array}{l}-1.6 \\
-4.3\end{array}$ & -1.0 \\
\hline $\begin{array}{l}\text { Comilla } \\
\text { Noakhali }\end{array}$ & $-173,456$ & $-151,107$ & $-15,445$ & -2.5 & $\begin{array}{l}-4.3 \\
-6.5\end{array}$ & $\begin{array}{l}-0.5 \\
-14\end{array}$ \\
\hline $\begin{array}{l}\text { Noakhali } \\
\text { Chittagong }\end{array}$ & $-145,991$ & $-123,385$ & $-26,590$ & $\begin{array}{r}-3.8 \\
2.5\end{array}$ & $\begin{array}{r}-6.5 \\
3.8\end{array}$ & $\begin{array}{r}-1.4 \\
0.9\end{array}$ \\
\hline Chittagong & 134,841 & 111,589 & 21,928 & 2.5 & $\begin{array}{r}3.8 \\
134\end{array}$ & $\begin{array}{l}0.9 \\
64\end{array}$ \\
\hline Chitt. H. T. & 69,178 & 42,488 & 16,764 & 11.9 & $\begin{array}{l}13.4 \\
15.0\end{array}$ & $\begin{array}{l}6.4 \\
6.7\end{array}$ \\
\hline Bandarban & 19,173 & 14,128 & 5,211 & 11.2 & & 6.7 \\
\hline
\end{tabular}

a. Less than 0.05 .

Sources: Census Commission 1975.

Bangladesh Bureau of Statistics 1984

\section{Patterns of Internal Migration, 1974-81}

On the basis of geographical and administrative set-up, Bangladesh is broadly divided into four major regions: Dhaka, Chittagong, Khulna and Rajshahi divisions. These are also designated as central, eastern, southern and northern regions, respectively (United Nations, 1981:30). Based on 
these divisions or regions, a broad regional pattern of net migration in Bangladesh for the period of 1974-81 is shown in Table 1. The central and northern regions gained more population than they lost, and the southern and eastern regions lost more than they gained. The gender differentials indicate a higher migratory movement for males than females in the central, northern and eastern regions. The southern region shows a higher female movement through net out-migration. However, from these broad regional patterns, a detailed explanation cannot be made. The focus should be on the smaller regions, that is, the districts.

Table 1 shows that seven out of 21 districts gained more people than they lost. Three of these net gaining districts (Rajshahi, Bogra, Dinajpur) are from the northern, three (Chittagong, Chittagong Hill Tracts, Bandarban) from the eastern, and only one (Dhaka) from the central region. The highest net gainer, in terms of rate, is Chittagong Hill Tracts (11.9\%), followed by Bandarban (11.2\%), and Dhaka (4.9\%). The lowest net gainer is Dinajpur (1\%). Among the net losers, Noakhali has the highest negative rate of balance (3.8\%), followed by Faridpur (2.7\%), Comilla (2.5\%), and Barisal (2.4\%). Khulna has a negligible net migration. All districts of the southern, all but one (Dhaka) of the central, three (Noakhali, Comilla and Sylhet) of the eastern, and two (Rangpur, Pabna) of the northern region experienced net migratory loss of population.

Although Chittagong Hill Tracts, Bandarban and Chittagong have the top, the second and the fourth highest net rates, respectively, in population gain, the eastern region as a whole is a net loser. This is because of the fact that the other three districts (Noakhali, Comilla and Sylhet) in this region have experienced a greater net loss which offsets the gain. On the other hand, despite the fact that all districts except Dhaka have a net losing rate, the central region shows a net population gain. For the net gain in thisregion, all credit goes to Dhaka, because it contains the capital city of the country (the largest city, containing about 4 million people in 1981).

From the above, it can be said that during 1974-81, the migratory flows were toward far north, centre, and south-eastern regions. Although it is difficult to determine, statements can be made on the features of the migratory flows that have appeared from the findings. First, people moved toward the rural areas of those districts in which the cultivating peasants are less pressured and employment opportunities are available in agricultural occupations. This may account for the net gains of the far northern region. Second, people moved toward urban areas. This is supported by the fact that among the four districts containing major cities (Dhaka, Chittagong, Khulna and Rajshahi), three experienced net gain. Khulna's net loss is negligible. Third, people also moved toward sparsely 
populated areas to settle. The net gains of the south-eastern region can be explained by this. The net gains of Chittagong Hill Tracts and Bandarban may also be a result of the Government's initiative to settle people in these areas as a part of the population redistribution program. The first and the third types of movement characterize the conservative migration; the second type characterizes innovative migration using Petersen's (1958) typology of migration.

TABLE 2. CENSUS SURVIVAL ESTIMATES OF AGE-SPECIFIC NET MIGRATION RATES BY DISTRICTS, BANGLADESH, 1974-1981

\begin{tabular}{|c|c|c|c|c|c|}
\hline \multirow[b]{2}{*}{ Districts } & \multicolumn{4}{|c|}{ Age Groups } & \multirow[b]{2}{*}{$57-66$ yrs. } \\
\hline & $17-26$ yrs. & $27-36$ yrs. & $37-46$ yrs. & $47-56$ yrs. & \\
\hline Dinajpur & 1.5 & 7.5 & 3.4 & -6.4 & -7.4 \\
\hline Rangpur & -3.9 & 1.0 & -2.7 & -8.0 & -0.4 \\
\hline Bogra & -1.4 & 4.2 & 4.5 & 0.2 & 5.4 \\
\hline Rajshahi & -0.1 & 4.6 & -1.2 & 8.2 & 11.6 \\
\hline Pabna & -4.1 & -5.7 & -7.8 & -5.5 & 8.5 \\
\hline Kushtia & -1.5 & -11.5 & -10.9 & -10.5 & 3.6 \\
\hline Jessote & -4.1 & -8.5 & -6.2 & -6.3 & 5.4 \\
\hline Khulna & -2.4 & 1.5 & 5.3 & 0.8 & -2.2 \\
\hline Patuakhali & -12.4 & 3.2 & 3.5 & 4.9 & 7.0 \\
\hline Barisal & -13.1 & -4.3 & 1.7 & -0.3 & 4.1 \\
\hline Faridpur & -14.0 & -7.9 & -4.6 & -0.1 & 9.1 \\
\hline Dhaka & 13.7 & 15.3 & 8.8 & 2.3 & -1.6 \\
\hline Tangail & -5.8 & -8.7 & -7.0 & -4.4 & 0.7 \\
\hline Mymensingh & -8.3 & -2.2 & 0.7 & 1.8 & 6.2 \\
\hline Jamalpur & -10.6 & 0.3 & 2.2 & 0.6 & 4.4 \\
\hline Sylhet & -9.0 & 3.7 & 4.9 & -3.8 & -3.9 \\
\hline Comilla & -14.5 & -8.7 & -2.8 & 0.9 & 7.4 \\
\hline Noakhali & -17.7 & -12.3 & -5.2 & -3.8 & -7.0 \\
\hline Chittagong & 7.6 & 5.0 & 3.9 & 8.2 & 4.4 \\
\hline Chitt. H. T. & 27.3 & 28.5 & 22.9 & 18.8 & 8.1 \\
\hline Bandarban & 22.9 & 31.4 & 28.2 & 20.0 & 6.2 \\
\hline
\end{tabular}

Sources: Census Commission 1975.

Bangladesh Bureau of Statistics 1984.

The gender differential in net migration rates is also presented in Table 1. Fourteen out of 21 districts show higher male migratory movements. The net gaining districts received more males than females. Among the net losing districts, Rangpur, Mymensingh and Jamalpur experienced a net gain of females over males, while all the net losing districts of the southern region lost more females than males. The considerable difference in male/female net migration rates was noticed in the districts with major cities and sparsely populated areas. 
The age selectivity of net migration in Bangladesh during 1974-81 is reflected in Table 2 . The highest migratory movements took place in the youngest age group of 17-26 years. Among the net gaining districts, all but Bogra and Rajshahi show a distinct pattern of positive net migration in the age groups of 17-26, 27-36 and 37-46 years. Chittagong, Chittagong Hill Tracts and Bandarban show a positive net balance for all age groups. For the net losing districts of Pabna, Kushtia, Jessore, Faridpur, Tangail, Comilla and Noakhali, a net loss was experienced in all age groups except the oldest one (57-66 years), while Khulna, Patuakhali and Jamalpur have a net gain in the age groups of 27-36, 37-46 and 47-56 years. An interesting pattern emerges from these findings. Most of the districts that lost more than they gained in the younger age groups, either experienced net gain or at least lost less in the older age groups, and vice versa. This pattern is distinctively clear for the age groups of $17-26$ and 57-66 years, a characteristic feature of return migration to the place of origin.

TABLE 3. CENSUS SURVIVAL ESTIMATES OF AGE-SPECIFIC NET MIGRATION RATES FOR MALES, BY DISTRICTS, BANGLADESH, 1974-1981

\begin{tabular}{|c|c|c|c|c|c|}
\hline \multirow[b]{2}{*}{ Districts } & & \multicolumn{2}{|c|}{ - Age Groups } & \multirow{2}{*}{$57-66$ yrs. } \\
\hline & $17-26$ yrs. & $27-36$ yrs. & $37-46$ yrs. & $47-56$ yrs. & \\
\hline Dinajpur & 3.7 & 6.2 & 4.5 & -2.0 & -5.7 \\
\hline Rangpur & -4.4 & 1.2 & -3.7 & -9.0 & -4.9 \\
\hline Bogra & -0.2 & 5.4 & 4.0 & 2.5 & 2.0 \\
\hline Rajshahi & 3.6 & 1.0 & 2.6 & 2.2 & 11.7 \\
\hline Pabna & -2.0 & -4.8 & -8.4 & -8.5 & 0.5 \\
\hline Kushtia & -2.5 & -9.2 & -9.2 & -10.3 & -3.5 \\
\hline Jessore & 1.0 & -6.0 & -7.8 & -6.0 & -1.4 \\
\hline Khulna & 3.4 & 3.7 & 8.3 & 2.8 & -7.1 \\
\hline Patuakhali & 13.7 & 2.1 & 2.6 & 5.8 & 10.3 \\
\hline Barisal & -9.3 & -6.7 & -0.4 & 2.5 & 5.2 \\
\hline Faridpur & -11.9 & -13.2 & -7.8 & -3.6 & 5.5 \\
\hline Dhaka & 21.4 & 21.3 & 12.8 & 3.6 & -4.8 \\
\hline Tangail & -5.1 & -12.0 & -11.4 & -7.4 & 6.4 \\
\hline Mymensingh & -7.9 & -3.9 & -1.0 & 1.4 & 2.3 \\
\hline Jamalpur & -14.3 & 0.4 & 0.7 & -0.3 & -5.8 \\
\hline Sylhet & -5.7 & $0.0^{\mathrm{a}}$ & 6.7 & -0.7 & -1.5 \\
\hline Comilla & -17.0 & -18.8 & -7.1 & -3.2 & 3.6 \\
\hline Noakhali & -22.2 & -27.0 & -16.9 & -9.1 & 3.4 \\
\hline Chittagong & 17.4 & 7.7 & 4.6 & 4.5 & 41.3 \\
\hline Chitt. $\stackrel{\text { H. }}{\text { T. }}$ & 26.1 & 34.1 & 25.6 & 33.3 & 10.3 \\
\hline Bandarban & 30.0 & 38.0 & 33.2 & 34.8 & 1.7 \\
\hline
\end{tabular}

a. Less than 0.05

Sources: Census Commission 1975.

Bangladesh Bureau of Statistics 1984. 
TABLE 4. CENSUS SURVIVAL ESTIMATES OF AGE-SPECIFIC NET MIGRATION RATES FOR FEMALES, BY DISTRICTS, BANGLADESH, 1974-1981

\begin{tabular}{|c|c|c|c|c|c|}
\hline \multirow[b]{2}{*}{ Districts } & \multicolumn{4}{|c|}{ Age Groups } & \multirow{2}{*}{$57-66$ yrs. } \\
\hline & $17-26$ yrs. & $27-36$ yrs. & $37-46$ yrs. & $47-56$ yrs. & \\
\hline Dinajpur & 5.8 & 7.4 & 1.8 & -38.7 & 29.8 \\
\hline Rangpur & 1.8 & $-0.0^{\mathrm{a}}$ & -3.7 & -4.6 & 0.5 \\
\hline Bogra & 3.7 & 1.6 & 3.7 & -4.1 & 0.2 \\
\hline Rajshahi & 1.5 & -7.6 & -4.3 & 11.0 & 2.8 \\
\hline Pabna & $-0.0^{\mathrm{a}}$ & -8.2 & -6.7 & -3.4 & 10.0 \\
\hline Kushtia & 0.3 & -14.5 & -12.0 & -12.2 & 3.2 \\
\hline Jessore & -3.0 & -11.7 & -8.2 & -5.2 & 4.1 \\
\hline Khulna & -1.0 & -1.0 & -24.9 & 1.3 & -4.1 \\
\hline Patuakhali & -6.4 & 3.3 & 4.8 & 1.0 & 1.9 \\
\hline Barisal & $-8.8 \mathrm{e}$ & -1.2 & 1.8 & -0.9 & -2.8 \\
\hline Faridpur & -8.9 & -3.4 & 0.2 & 4.6 & 9.5 \\
\hline Dhaka & 12.9 & 7.7 & 2.9 & -0.8 & 1.4 \\
\hline Tangail & 0.2 & -7.3 & 4.2 & -3.8 & 2.1 \\
\hline Mymensingh & -2.1 & 0.1 & 3.1 & -0.8 & 5.0 \\
\hline Jamalpur & 1.6 & 1.4 & 3.2 & 1.6 & 7.3 \\
\hline Sylhet & -5.8 & 7.1 & 4.2 & -7.3 & -9.3 \\
\hline Comilla & -5.4 & $0.0^{\mathrm{a}}$ & 2.2 & 3.1 & 6.1 \\
\hline Noakhali & -8.3 & -2.6 & 5.1 & 2.4 & 1.1 \\
\hline Chittagong & 4.0 & 2.8 & 1.1 & 2.1 & 1.5 \\
\hline Chitt. H.T. & 19.6 & 19.9 & 16.7 & -5.5 & -0.8 \\
\hline Bandarban & 21.6 & 22.0 & 22.8 & -10.2 & 11.8 \\
\hline
\end{tabular}

a. Less than 0.05 .

Sources: Census Commission 1975.

Bangladesh Bureau of Statistics 1984.

The gender differential in age selectivity is presented in Tables 3 and 4 . The results show that all south-eastern districts gained more males than females in all age groups. All the major city-containing districts except Rajshahi gained more males than females in all age groups but the last one (57-66 years). Fourteen out of 21 districts experienced opposite directions of movement between the youngest and the oldest age groups for males, whereas this pattern is less clear for females. Although it appears that the three age groups (17-26, 27-36 and 37-46 years) seem to be dominant in migratory movements for both males and females, the other age groups also show considerable degrees of mobility. It is because (a) females migrate in the earlier age due to marriage, in middle age to join their husbands, and in older age to join the children's family either as dependents or as helping hands; and (b) males migrate in the earlier age in search of work, in middle age due to changes either in occupation or work place, and in older age to return home after retirement. The unclear pattern in the indication of return migration for females may be attributed 
to the fact that some male migrants might have left their wives or rest of the family permanently at the place of origin and visited them in the vacations or holidays. This is not unexpected in a traditional society like Bangladesh.

\section{Determinants of Internal Migration}

Bangladesh is a country of traditional agrarian structure with probably the highest population density in the world. The vast majority of its total population is dependent on agriculture. The technology of production is backward and unchanging with low productivity. Ownership of land in Bangladesh is highly concentrated (Jannuzi and Peach, 1980) and the degree of concentration is on the increase. The change in the distribution of land ownership is generally attributed to the rapid fragmentation of land into small holdings. The inability of many of the small landholdings to remain viable has led to the increasing number of landless agricultural labourers in the country. The main reason for this is believed to be the high rate of population growth and the limited supply of land (Chaudhury, 1981). This approach suggests that the high growth rate of population significantly determines the migratory flows in the country by placing excessive pressure on the limited land available for agricultural production. In other words, loss and gain of population in a region is closely related to the high population pressure/density (Krishnan and Rowe, 1978; Bangladesh Bureau of Statistics, 1984; and Elahi and Sultana, 1985).

This does not seem to be an adequate explanation of the real situation. Adnan (1982) holds that in a country like Bangladesh, high population growth is a result of the historical development of relations between land and labour. Jannuzi and Peach (1980) demonstrate that the social structure of the country reflects unequal hierarchical relations of people to the land, which is rooted in the historical evolution of the land tenure system of the region (for details on the evolution of land reforms and agrarian change, see Abdullah, 1976; Jannuzi and Peach, 1980). The land system evolved in such a way that the distribution of rights and privileges in land always favoured landowners with large holdings. It is a structure that favours those who have secured rights and privileges in land with the benefits of the structural developmental programs of the country. These secured and superior rights and privileges have enhanced the landowner's bargaining power to push the rental rate high driving the share of the labourers below the subsistence level (Adnan, 1982:217). Under this insecure condition, the cultivating peasants find the generation of surplus population advantageous for survival. But this generation of surplus population aggravates the situation to the point that the sharecroppers, the small farmers and the landless labourers compete among themselves to 
obtain access to the limited land available for cultivation. According to this approach, these relationships condition the process in which people are forced to move sectorally and then spatially to areas where the pressure is less and work is available (Adnan, 1982; Jannuzi, 1988). Therefore, it can be assumed that in an agrarian country like Bangladesh internal migration is determined by the exploitative unequal relations of people to the land along with the high population growth rate.

Two major hypotheses can be put forward to test: (a) the greater the extent of exploitative relations of people to the land in a district, the greater the extent of net loss of population; and (b) the higher the population growth rate in a district, the higher the extent of net loss of population. But with the data available, it is possible to test these hypotheses only indirectly. In the regression model, the activity rate, "defined as the ratio of economically active population 10 years and over to the total population of all ages and expressed in percentage" (Bangladesh Bureau of Statistics, 1984:112), in a given district has been considered as an indicator of the extent of exploitation. The activity rate not only represents an approximate measure of the size of the labour force, but also provides an indication of better employment opportunities in the sense that a place with better employment opportunities will attract economically active people (both employed and unemployed) more than a place with less promise. We assume that the employment opportunities are related to the terms and conditions for the rental rate of land and the share of the produced crops. If these terms and conditions are exorbitant in a district, the activity rate will be low and, consequently, that district will experience a negative net migration. This is reflected in the patterns of internal migration (presented earlier) in Bangladesh. Net gain of urban areas, especially the big cities, suggest the availability of better facilities and amenities for living, and a low degree of exploitation. The same applies to the other net gaining districts where rural to rural migration seems to be predominantly strong. For the extent of population growth rate or the extent of population pressure on land, the population density per square mile of net cropped area instead of the simple population density per square mile is considered as an indicator.

To make the model more explanatory and meaningful, other sociodemographic variables (such as urbanization rate, literacy rate, proportion of never-married persons and average household size) should be included in the analysis. In countries like Bangladesh, urbanization is mainly the result of rural to urban migration. Any study of internal migration in Bangladesh cannot be adequate without touching upon the relationship between migration and urbanization. Billsborrow and 
Winegarden (1982) hold that rate of urbanization is so powerful that if one disregards the absorptive capacity of cities, the macro level studies of migration in low-income countries are likely to be seriously biased. Rate of urbanization is defined as the percentage of population living in areas that are defined as urban (according to Census Commission [1975:53], usually a population of approximately 5,000 or more). An educational selectivity of migration is universally recognized. It is considered that the higher the educational level of people in an area, the more likely people are to be aware of differential opportunities and amenities in alternative places, and the more likely they are to migrate (Shaw, 1975). The measure used for education is literacy rate, expressed in percentage of population aged five years and above who could read and write a letter in any language. Nevermarried or single persons are expected to migrate for education and employment more than married persons. They are young, and do not have family ties that can pull them back, consequently; they can be aggressive and take risks in new ventures at other promising places. Higher average household size is expected to have a negative relationship with migration. Inability of large families to provide adequate support to all the members forces some of their members to move out to places with employment opportunities, and also members of large families from the upper stratum of society move out to seek opportunities to fulfill their aspirations.

It is hypothesized that any district with a high literacy rate, high proportion of never-married persons and large household size is likely to lose more people than it gains; and any district with a high urbanization rate is likely to gain more than it loses. Although some of the measures, for example, literacy rate, are not adequate to explore the detailed effects on the net migration rate, it is hoped that the selected socioeconomic and demographic variables as determinants of net migration will give an indication of the actual situation of the country. The relevant data are presented in Table 5.

\section{Results and Discussion}

The results of the regression analysis are presented in Table 6. It shows that the regression model explains 93 per cent of the variance in the dependent variable. Among the explanatory variables, only activity rate and urbanization rate $(r=0.272, p>0.05)$ are found to have statistically significant effects on net migration at the 0.001 and 0.01 levels, respectively. While the activity rate alone explains 81.5 per cent of the total variance in net migration rate, the urbanization rate explains 5.9 per cent. It is quite normal for people to move to areas where better occupational opportunities are available. Previous studies (for example, Stoeckel et al., 1972; Chaudhury and Curlin, 1975; Begum, 1979) confirm 
TABLE 5. SELECTED SOCIOECONOMIC AND DEMOGRAPHIC CHARACTERISTICS OF THE DISTRICTS IN BANGLADESH, 1974

\begin{tabular}{lrrrrrrr}
\hline DISTRICTS & NMR & DSMNCA & AHHS & UR & AR & LR & PNMP \\
\hline Dinajpur & 1.0 & 1324 & 5.3 & 4.4 & 30.5 & 21.5 & 31.2 \\
Rangpur & -0.4 & 2169 & 5.6 & 4.8 & 29.0 & 16.2 & 29.7 \\
Bogra & 1.6 & 1920 & 5.4 & 3.7 & 27.9 & 22.1 & 29.3 \\
Rajshahi & 2.0 & 1609 & 5.7 & 5.8 & 27.4 & 19.4 & 31.2 \\
Pabna & -0.6 & 1895 & 6.1 & 7.6 & 27.4 & 18.6 & 34.0 \\
Kushtia & -1.7 & 1872 & 6.2 & 8.3 & 26.8 & 16.9 & 33.5 \\
Jessore & -1.4 & 1730 & 6.1 & 5.4 & 26.0 & 22.5 & 34.1 \\
Khulna & $0.0^{\mathrm{b}}$ & 2189 & 5.7 & 14.6 & 28.4 & 28.5 & 33.8 \\
Patuakhali & -0.7 & 1380 & 5.2 & 2.5 & 27.7 & 27.7 & 30.0 \\
Barisal & -2.4 & 2121 & 5.4 & 3.9 & 27.2 & 30.2 & 34.3 \\
Faridpur & -2.7 & 2070 & 5.6 & 2.9 & 27.7 & 20.3 & 34.4 \\
Dhaka & 4.9 & 3697 & 5.8 & 29.6 & 30.4 & 26.3 & 36.3 \\
Tangail & -2.0 & 2261 & 6.0 & 5.2 & 26.8 & 17.9 & 33.9 \\
Mymensingh & -0.7 & 1983 & 5.4 & 6.0 & 29.6 & 13.6 & 31.7 \\
Jamalpur & -0.3 & $1566^{\mathrm{c}}$ & 5.6 & 4.6 & $29.6^{\mathrm{a}}$ & 12.9 & 30.3 \\
Sylhet & -1.3 & 1621 & 5.5 & 2.8 & 30.6 & 20.2 & 35.4 \\
Comilla & -2.5 & 2742 & 5.7 & 4.2 & 28.5 & 23.8 & 33.6 \\
Noakhali & -3.8 & 2185 & 5.5 & 2.2 & 26.2 & 26.2 & 34.8 \\
Chittagong & 2.5 & 3654 & 5.6 & 21.0 & 30.6 & 29.7 & 39.3 \\
Chitt. H.T. & 11.9 & 1828 & 5.3 & 9.8 & 44.0 & 17.6 & 34.1 \\
Bandarban & 11.2 & $66^{\mathrm{C}}$ & 5.3 & 11.5 & $38.6^{\mathrm{a}}$ & 9.2 & 33.6 \\
& & & & & & & \\
\hline NMR = Net Migration Rate
\end{tabular}

NMR = Net Migration Rate

DSMNCA = Density per Square Mile of Net Cropped Area

AHHS $=$ Average Household Size

UR = Urbanization Rate

$\mathrm{AR}=$ Activity Rate

LR = Literacy Rate

PNMP = Proportion of Never-Married Persons

a. Taken as proxy from Statistics 1984 .

b. Less than 0.05 .

c. Density per square mile area instead of density per square mile of net cropped area.

Sources: Census Commission 1975.

Bangladesh Bureau of Statistics 1978.

Bangladesh Bureau of Statistics 1984.

this as the main reason for migration in Bangladesh. These studies indicate that the vast majority of migrants moved toward urban areas, and conclude that rural to urban migration is the dominant flow of migration. Skeldon (1985:44), however, argues from the 1974 census findings that rural to rural migration (47.2\%) is still predominant in Bangladesh. He shows that only when one combines both rural to urban (40.2\%) and urban to urban $(11.0 \%)$ migration rates, are migratory movements toward urban areas slightly higher than toward rural areas. It is true that the urban centres are recipients of a significant proportion of rural migrants, but the main concentration of these rural migrants occurs in the major cities. The concentration of rural migrants in the major cities along with the migrants 
from other urban areas generate a new feature in the urban growth of the country. That is, the largest towns in the country seem to be growing the fastest (United Nations, 1981:25-27; Chaudhury, 1980:23-25), while the small towns are probably dying through losing more population than they gain. The 1981 census reveals that the number of towns containing less than 25,000 people has decreased from 65 in 1974 to 19 in 1981. This may be due partly to the change in definition of urban areas or reclassification of areas as urban and rural, and partly to the fact that small towns are failing to provide incentives in terms of jobs and business.

TABLE 6. REGRESSION COEFFICIENTS WITH THEIR STANDARD ERRORS AND R-SQUARE CHANGE BY THE EXPLANATORY VARIABLES ( $\mathrm{N}=21$ DISTRICTS)

\begin{tabular}{lllll}
\hline $\begin{array}{l}\text { Explanatory } \\
\text { Variables }\end{array}$ & $\begin{array}{l}\text { Dependent } \\
\text { Variable } \\
\text { (Intercept) }\end{array}$ & $\begin{array}{l}\text { Unstd. Regn. } \\
\text { Coeffs. (b) } \\
\text { (Std. Errors) }\end{array}$ & $\begin{array}{l}\text { Std. Regn. } \\
\text { Coeffs. (B) } \\
\text { (Std. Errors) }\end{array}$ & $\begin{array}{l}\text { R-Square } \\
\text { Change }\end{array}$ \\
\hline AR & $\begin{array}{l}\text { NMR } \\
\left(-14.20^{*}\right)\end{array}$ & $\begin{array}{l}.82^{* * *} \\
(.098)\end{array}$ & $\begin{array}{l}.84^{* * *} \\
(.101)\end{array}$ & .815 \\
UR & & $\begin{array}{l}.23^{* *} \\
(.066)\end{array}$ & $\begin{array}{l}.38^{* *} \\
(.108)\end{array}$ & .059 \\
PNMP & & -.34 & -.20 & $.098)$ \\
AHHS & & $(.168)$ & $(.098)$ & .036 \\
& & .019 & .12 & .010 \\
DSMNCA & & $(.014)$ & $(.088)$ & .008 \\
& & -.0031 & -.066 & $(.131)$ \\
LR & & $(.006)$ & -.0066 & .000 \\
& & -.0047 & $(.102)$ & \\
\hline
\end{tabular}

R-square $=.928$

Adjusted R-square $=897$

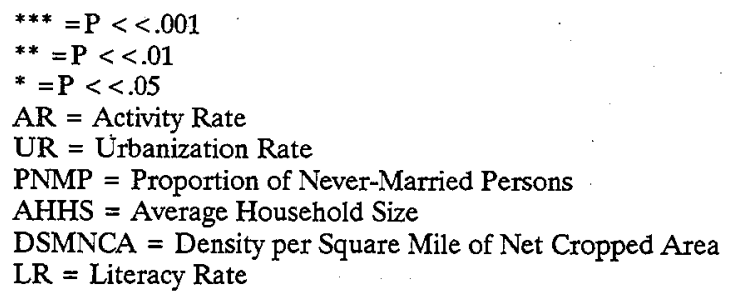


According to the second major research hypothesis, it was expected that densely populated areas tend to lose more people than they gain. Studies by Haque (1977), Krishnan and Rowe (1978) and Elahi and Sultana (1985) find the expected result. However, the result of the regression analysis of this study does not support this. It is evident from Table 5 that many districts with high density gained more than they lost, while others with low density lost more than they gained. The high explanatory power of activity rate and the insignificant effect of population density suggest that population pressure is not a primary determinant of migration in Bangladesh. Rather, the unequal and exploitative agrarian relations resulting from the disparity in rights and privileges between the landowners and the actual cultivators of the soil generate the rates and directions of net migration. In other words, the majority of the migratory movements in Bangladesh seem to be determined by the forces in the social relations of production through the interaction between man and man. The review of the historical evolution of land relations of the country and the findings of the regression analysis lead to a conclusion in that direction: However, further study is needed to confirm the contention directly through a special survey involving information on credit relations, land concentration, landlessness and migratory movements.

The influence of the other determinants, such as the literacy rate, the proportion of never-married persons and the average household size are not clear, as they fail to achieve statistical significance. Chaudhury (1978) finds that the overall educational level of migrants is higher than that of the non-migrants, and the propensity to migrate increases with the increase in education beyond secondary level. The 1981 census shows that slightly over three per cent of the total population of the country has education beyond the secondary school certificate level (Bangladesh Bureau of Statistics, 1984:93). Although it is beyond the scope of this study due to the lack of district-specific data on level of schooling, it can certainly be assumed that this highly selected group has a greater aspiration to better itself, and tends to move more than the less educated group. However, when it comes to the total net migrants of each district, this high selection no longer dominates. Most of the migrants seem to be unskilled manual labourers, landless agricultural labourers, small business men and housewives (Stoeckel et al., 1972; Chaudhury and Curlin, 1975; Chaudhury, 1978; Begum, 1979). Therefore, it can be stated that migration takes place in Bangladesh regardless of educational level.

The never-married persons are always in an advantageous position to migrate because they are young and have fewer family ties. Therefore, it is expected that the districts with a greater proportion of never-married 
persons tend to lose more people than they gain. It should be noted that while this is true for males, the opposite is the case for females. Females generally move out as housewives and dependents (Stoeckel et al., 1972; Chaudhury and Curlin, 1975). The proportion of never-married persons as an indicator of marital status fails to achieve statistical significance and explains only 3.6 per cent of the total variance in the dependent variable. The use of the figures for the proportion of never-married persons from the 1981 data source as proxy for the 1974 situation may have a bearing on this. In addition, the proportion of never-married persons is relatively low and not widely varied among the districts because of the prevalence of universal and early marriage in Bangladesh.

The reason for the statistically non-significant effect of the average household size is obvious. The average household size of the districts has not varied very much, even though it is comparatively high in all districts. Stoeckel et al. (1972) and Chaudhury and Curlin (1975) have found that in Bangladesh, out-migration is higher among the smaller and the larger sized households. They suggest that the high rate among the small sized may be due to the presence of unrelated or single individuals who generally represent the most mobile segment of the population. The high rate among the large sized households may result either from the pressure exerted by the families themselves for adequate support of all the members, or from the better socioeconomic position of larger families. Studies by Asaduzzaman (1973) and Chaudhury (1981) have shown that larger families are positively associated with larger landholding sizes. It can be argued that members of the rich and large families may not need to move, because they can provide adequate support for themselves. On the other hand, they are the prime candidates to move for the betterment of their rank in the socioeconomic status.

Two other models have been developed to examine the differential effects of the explanatory variables on male/female net migration rates. The results (not presented here), in terms of the statistical significance, do not differ from the model discussed above. The same two variables (activity rate and urbanization rate) have effects on both male and female net migration rates. The differences in the magnitude of the effects of the other explanatory variables, which indicate their relative importance, are noticed, but they are not substantial.

\section{Summary and Conclusions}

An attempt has been made to study the patterns and the determinants of internal net migration in Bangladesh for the period 1974-81. The census reports of 1974 and 1981 were used as data sources. In the absence of 
direct data, the census survival ratio method was used to estimate the net migration rate for 21 districts of Bangladesh. A multiple regression model was devised to examine the effects of selected socioeconomic and demographic explanatory factors on migration.

The data analysis reveals that people moved toward rural areas of the northern and sparsely populated areas of the southern-eastern regions, where the exploitative pressure from land relations seemed to be less. These movements chararacterize conservative migratory movements. People also moved toward major urban areas, which characterizes innovative migratory movements. The migratory flows were toward the north, central and south-eastern districts. The majority of the districts showed higher male than female migratory movements during 1974-81. The highest migratory movements took place among the younger people. An indication of return migration is noted. Although somewhat speculative, this study points to two additional observations: that rural to rural migration is still predominant in Bangladesh; and that the small towns are dying through losing more people than gaining. This is to say that small towns probably are not serving as primary stepping stones for big city migration.

The statistical findings of the regression analysis fail to support the thesis that high population growth/density determines the migratory flows in Bangladesh by placing excessive pressure on the limited land available for agricultural production. On the contrary, the activity rate as an indicator of the extent of exploitation accounts for 81.5 per cent of the explained variance in the dependent variable. This suggests that population density may put pressure on land in a traditional agrarian society, where the industrial, service and tertiary sectors are not developed enough to absorb the surplus labour force; but the interacting forces of the unequal hierarchical land relations play a major role in determining the spatial movement of the population. That is, the exploitative agrarian relations of production through the interaction between man and man seem to play a significant role in the determination of most of the migratory movements in Bangladesh.

However, in view of the nature of the data set used in the study, the findings should be treated with caution. For a direct conclusion, as well as to comprehend the whole dynamics of internal migration in Bangladesh, a more rigorous study through a special survey is necessary involving information on credit relations, land concentration, landlessness and migratory movements. In conclusion, it can be said that this study has 
indicated support for the overall argument posed to understand the patterns and the determinants of net migration in Bangladesh.

\section{Acknowledgments}

This is a revised version of a paper presented at the Annual Meeting of the Canadian Population Society, Learned Society Meetings, 5-7 June 1989, Université Laval, Quebec City, Quebec, Canada. This paper is based on one of the Area Specialization Papers submitted to the Committee as a partial fulfilment of the requirements of the $\mathrm{Ph}$. D. program in the Department of Sociology at the University of Alberta. The author is indebted to Professors P. Krishnan, W.W. McVey, L.A. Kosinski and F. Trovato of the University of Alberta, Edmonton, Canada, for their critical comments and helpful suggestions. The author is also grateful to the two anonymous referees for their valuable comments on an earlier draft of this paper.

\section{References}

Abdullah, A. 1976. Land reforms and agrarian change in Bangladesh. The Bangladesh Development Studies 4(1):67-114.

Adnan, S. 1982. Conceptualizing fertility trends in peripheral formations. In C. Hohn and R. Mackensen (eds.), Determinants of Fertility. Trends: Major Theories and New Directions for Research. Ordina edition. Liege, Belgium: International Union for the Scientific Study of Population.

Asađuzzaman, M. 1973. Kaligang villages - An economic survey. Dhaka: Bangladesh Institute of Development Studies (mimeo).

Bangladesh Bureau of Statistics. 1978. Statistical Pocket Book of Bangladesh. Dhaka: Ministry of Planning.

.1984. Population Census of Bangladesh 1981: Analytical Findings and National Tables. Dhaka: Ministry of Planning.

Begum, J. 1979. Rural-urban migration: A survey of the poor women in two localities of Metropolitan Dhaka (in Bengali). Department of Geography, University of Dhaka.

Billsborrow, R.E. and C.R. Winegarden. 1982. Interrelationships between demographic change and agricultural development: A cross-country econometric exploration. Paper presented at the Annual Meeting of the Population Association of America, 29 April1 May, San Diego, California.

Census Commission. 1975. Bangladesh Population Census 1974. Bulletin no. 2. Census Publication no. 26. Dhaka: Ministry of Home Affairs.

Chaudhury, R.H. 1978. Determinants and consequences of rural out migration: Evidence from some villages in Bangladesh. Oriental Geographer 22 (1 and 2): 1-20. . 1980. Urbanization in Bangladesh. Dhaka: Centre for Urban Studies.

. 1981. Effect of population growth on changes in the agrarian structure of rural Bangladesh. Social Action (New Delhi) 31(3):336-50.

and G.C. Curlin. 1975. Dynamics of migration in a rural area of Bangladesh. Bangladesh Development Studies 3(2):181-230.

Elahi, KM. 1972. Urbanization in Bangladesh: A geodemographic study. Oriental Geographer 11:23-35.

and S. Sultana. 1985. Population redistribution and settlement change in South Asia: A historical evolution. In L.A. Kosinski and KM. Elahi (eds.), Population Redistribution and Development in South Asia. Dordrecht: D. Reidel Publishing.

Haque, C.E. 1977. Spatial structure of the labour force in Bangladesh. Postgraduate thesis. Dhaka: Jahangirnagar University. 
Huq, Z.S. 1973. Determinants of spatial dynamics of population movement within Bangladesh. Unpublished Ph.D. thesis. Department of Geography, University of British Columbia, Canada.

Hussain, A.Z.M.W. 1972. Squatting and squatters in Dhaka city. Unpublished Master's thesis. Department of Geography, University of Dhaka.

Jannuzi, F.T. 1988. Economic development in Bangladesh through retention of the rural population. In J. Havet (ed.), Staying On: Retention and Migration in Peasant Societies. Ottawa: University of Ottawa Press.

and J.T. Peach. 1980. The Agrarian Structure of Bangladesh: An Impeđiment to Development, Boulder, Colorado: Westriew Press.

Khan, I.A. 1969. Causes and effects of rural-urban migration in Pakistan. Rural Development Administration 6(4).

Kosinski, L.A. 1975. Data and measures in migration research. In L.A. Kosinski and R.M. Prothero (eds.), People on the Move: Studies on. Internal Migration. London: Methuen and Co.

Krishnan, P. and G. Rowe. 1978. Internal migration in Banglađesh. Rural Demography 5(1 and 2):1-21.

Obaidullah, M. 1967. Internal migration in East Pakistan. Oriental Geographer 11:23-35.

Petersen, W. 1958. A general typology of migration. American Sociological Review 23:256265.

Shaw, R.P. 1975. Migration Theory and Fact: A Review and Bibliography of Current Literature. Pennsylvania: Regional Science Research Institute.

Simmons, A., S. Diaz-Briquets, and A.A. Laquian (eds.) 1977. Social Change and Internal Migration: A Review of Research Findings from Africa, Asia and Latin America. Ottawa: International Development Research Centre.

Skeldon, R. 1985. Migration in South Asia: An overview. In L. A. Kösinski and K. M. Elahi (eds.), Population Redistribution and Development in South Asia. Dordrecht: D. Reidel Publishing.

Stoeckel, J., A.K.M. Chowdhury and K.M.A. Aziz. 1972. Out-migration from a rural area of Bangladesh. Rural Sociology 37(2):236-245.

United Nations. 1956. Methods for Population Projections by Sex and Age: Manuals on Methods of Estimating Population. Manual III. Population Studies no. 25. New York: Department of Economic and Social Affairs.

. 1970. Methods of Measuring Internal Migration. Manual VI. Population Studies no. 47. New York: Department of Economic and Social Affairs. 1981. Population of Bangladesh. Country Monograph Series no. 8. Bangkok: Economic and Social Commission for Asia and the Pacific.

Received August, 1990; revised October 1991. 